\title{
TANAMAN PAKAN LEGUMINOSA DALAM SISTEM INTEGRASI DENGAN PERKEBUNAN JERUK
}

\author{
Rijanto Hutasoit, Andi Tarigan, Juniar Sirait \\ Loka Penelitian Kambing Potong, PO Box I Sungei Putih, Galang 20585, Sumatera Utara \\ E-mail: h.rijanto@yahoo.com
}

\begin{abstract}
ABSTRAK
Penelitian bertujuan untuk mengetahui karakteristik morfologi dan potensi beberapa tanaman legum sebagai sumber pakan dan cover crop di lahan perkebunan jeruk, empat spesies legum yang digunakan yaitu: Arachis glabrata, Stylosanthes guianensis, Clitoria ternatea dan Chamaecrista rotundifolia. Uji potensi dilakukan dilahan perkebunan jeruk seluas $1200 \mathrm{~m}^{2}$ dalam rancangan acak lengkap dengan empat perlakuan (spesies legum) dan tiga ulangan. Karakteristik morfologi menunjukkan Stylosanthes guianensis adalah tanaman tertinggi $(78,03 \mathrm{~cm})$, Clitoria ternatea memiliki daun terlebar $(31,14 \mathrm{~mm})$ dan terpanjang (47,27 mm), Arachis glabrata memiliki jumlah daun terbanyak (125,46 lembar), sedangkan Chamaecrista rotundifolia memiliki rasio daun: batang tertinggi $(1,77)$. Warna hijau pada daun dimiliki oleh Stylosanthes guianensis, sedangkan ketiga jenis lainya berwarna hijau muda. Produksi bahan kering $(\mathrm{BK})$ tertinggi $(\mathrm{P}<0,05)$ pada Stylosanthes guianensis (22,67 ton ha ${ }^{-1}$ tahun $\left.^{-1}\right)$. Komposisi kimiawi menunjukkan kadar BK tertinggi $(\mathrm{P}<0,05)$ pada tanaman Stylosanthes guianensis (27,72\%). Clitoria ternatea memiliki protein kasar (PK) tertinggi $(17,16 \%)$ dan serat kasar (SK) terendah (29,80\%). Kanndungan nitrogen (N) pada tanah naik pada akhir kegiatan, tertinggi pada Stylosanthes guianensis (0,21\%). Disimpulkan bahwa jenis Stylosanthes guianensis dan Clitoria ternatea merupakan tanaman yang banyak keunggulan sebagai sumber pakan dan cover crop dalam sistem integrasi dengan perkebunan jeruk.
\end{abstract}

Kata kunci: leguminosa, integrasi, cover crop, tanaman pakan

\section{PENDAHULUAN}

Tanaman legum sangat potensial sebagai suplemen protein untuk ternak ruminansia karena kandungan Nitrogen yang cukup tinggi (Horne dan Stur. 1999). Namun pengadaanya masih terkendala karena keterbatasan lahan dalam pengembangannya. Sebenarnya masih banyak areal/lahan yang masih kosong belum termanfaatkan untuk digunakan sebagai sumber pakan ternak, seperti sumber daya perkebunan jeruk, bayak terdapat lorong-lorong perkebunan (gawangan) yang masih kosong yang dapat dimanfaatkan dengan sistem pertanaman lorong aAlley cropping) tanpa merusak kelestarian sumberdaya tanaman jeruk. Integrasi tanaman pakan diperkebunan jeruk adalah dengan melibatkan komponen tanaman jeruk dengan hijauan pakan di lahan/gawangan di antara tanaman. Dalam sistem ini komponen gawangan merupakan subsistem pendukung, sedangkan tanaman jeruk adalah merupakan subsistem utama. Hal ini disebabkan oleh karena tanaman pakan merupakan sistem yang harus beradaptasi dengan tanaman jeruk.

Dalam sistem integrasi tanaman legum sebagai pakan ternak dengan tanaman jeruk akan mendukung pengembangan usaha peternakan rakyat. Selain digunakan sebagai pakan ternak tanaman legum juga sebagai cover crop yang dapat menyuburkan tanah karena kemampuannya meningkatkan ketersediaan $\mathrm{N}$ pada tanaman oleh bintil akar yang mengandung Rhizobium (Moulin et al., 2001) melarutkan fosfat dari kompleks Ca-P, A1-P, dan toleransinya terhadap kondisi tercekam (kemasaman aluminiun dan kekeringan). Menurut Somantri et al. (2005) Rhizobium selalu mampu meningkatkan kemampuan tanaman mengikat $\mathrm{N}$ udara, sehingga pembentukan bintil akar dan produktivitas tanaman meningkat. Hal senada juga diutarakan oleh Mansyur (2008) dalam pembentukan bintil akar, aktivitas bakteri Rhizobium pada tanaman leguminosa memberikan cukup $\mathrm{N}$ sehingga tanaman akan mempunyai sistem perakaran yang lebih besar serta menyebar dan akhirnya penyerapan unsur hara akan bertambah. Menurut (Saraswati et al. 1996), dapat menekan kebutuhan urea dan TSP hingga 40-50\%.

Tentunya tidak semua tanaman legum dapat tumbuh dengan baik dengan sistem integrasi, dengan demikian tujuan penulisan ini untuk mengetahui karakteristik morfologik, produksi, komposisi nutrisi serta kandungan nitrogen tanah pada beberapa tanaman pakan leguminosa dalam sisitem integrasi dengan perkebunan jeruk. 


\section{MATERI DAN METODE}

\section{Ruang Lingkup Kegiatan}

Kegiatan ini dilaksanakan di Kabupaten Tanah Karo, Sumatera Utara, terletak pada ketinggian \pm $800 \mathrm{~m}$ dari permukaan laut, curah hujan $\pm 1200 \mathrm{~mm} /$ thn. Lahan yang digunakan adalah areal perkebunan jeruk yang masih muda umur tanaman 2-3 tahun seluas $1200 \mathrm{~m}^{2}$ dengan jenis tanah adalah andisol berwarna hitam pada lapisan atas dengan $\mathrm{pH}$ tanah antara 4,0 - 5,o. Waktu penelitian dilaksanakan pada bulan Januari sampai dengan Desember 2014.

Bahan dan Metode Pelaksanaan Kegiatan

Kegiatan diawali dengan persiapan lahan, pengolahan tanah secara manual, dilanjutkan pembuatan petakan (plot) sebanyak 4 plot perlakuan dengan 3 ulangan penelitian sehingga diperoleh sebanyak 12 plot perlakuan. Luas satu plot perlakuan adalah $9 \times 10 \mathrm{~m}$ didalamnya terdapat 4 batang tanaman jeruk dengan jarak tanam 4,5 $\times 5 \mathrm{~m}$. jarak antara petak perlakuan akan dibuat jarak o,5 m sebagai drainase. Bahan yang digunakan dalam penelitian ini yaitu 4 jenis benih tanaman leguminosa yang sudah familiar digunakan sebagai pakan ternak, antara lain: Stylosanthes guianensis, Arachis glabrata, Clitoria ternatea, dan Chamaecrista rotundifolia, diperoleh dari kebun koleksi hijauan pakan ternak Loka Penelitian Kambing Potong Sungei Putih, sebanyak 0,5 kg masing-masing biji leguminosa disemai pada tanah yang gembur dan diberikan naungan untuk menghindari hujan dan cahaya matahari langsung. Setelah dua minggu kemudian biji yang disemai sudah tumbuh sekitar $2 \mathrm{~cm}$ siap untuk dimasukkan kedalam polybag kecil ukuran $1 / 4 \mathrm{~kg}$, pada umur satu bulan kemudian tinggi tanaman $\pm 20 \mathrm{~cm}$ dipindahkan ke lahan penelitian (kebun jeruk) dengan jarak tanam $0,5 \times 0,5 \mathrm{~m}^{2}$. Seluruh tanaman legum ditanam di sekitar pohon jeruk dengan sistem alley cropping, jarak penanaman legum dari pohon jeruk adalah $1 \mathrm{~m}$. Pemupukan dilakukan pada saat sebelum dilakukan pengolahan tanah, pemberian pupuk kandang/kompos pada seluruh lahan dengan dosis 20 ton/ha, kapur (dolomit) 5 ton/ha. Kontrol terhadap gulma dilakukan penyiangan pada unur 21 hari setelah tanam untuk menghilangkan gulma penyaing tanaman. Selanjutnya dilakukan pemotongan (panen) pada umur 90 hari setelah tanam (HST) yaitu pada saat menjelang berbunga untuk mengetahui jumlah produksi tanaman legum.

\section{Variabel pengamatan}

\section{Produksi tanaman}

Untuk memeperoleh data produksi tanaman dilakukan pemotongan dengan tinggi $20-25 \mathrm{~cm}$ di atas permukaan tanah. Setiap melakukan pemotongan (panen) dilakukan penimbangan biomassa untuk memperoleh data produksi dan pengambilan sampel (500 g/plot) dilakukan untuk analisis komposisi kimiawi terhadap kandungan $\mathrm{N}$ (Kjeldal), kandungan bahan kering (BK), serat kasar (SK), dan bahan organik (BO) dianalisis menurut AOAC (2005).

\section{Karakteristik Morfologi}

1. Tinggi tanaman, diukur dengan menggunakan meteran dari dasar (pangkal) sampai ujung titik tumbuh tertinggi tanaman.

2. Lebar daun, dengan menggunakan alat ukur dari titik pinggir pertengahan daun

3. Panjang daun, diukur dari pangkal daun sampai ujung daun

4. Jumlah daun, dilakukan dengan teknik pengambilan sampel yang sama dengan dengan mengitung seluruh jumlah helai daun yang ada pada batang tanaman.

5. Rasio daun dan batang, dilakukan dengan mengambil hasil biomassa sebanyak $500 \mathrm{~g}$, selanjutnya dipisahkan daun dan ranting kemudian ditimbang kembali masing-masing fraksi untuk mendapatkan rasio daun dan batang.

6. Warna daun, ditentukan dengan bagan warna daun (BWD) dengan cara daun ditempelkan sesuai dengan warna BWD.

\section{Kandungan Nitogen (N) pada tanah}

Dilakukan dengan mengambil sampel tanah sebanyak $500 \mathrm{~g}$ dengan cara dibor kedalaman $20 \mathrm{~cm}$ jarak $10 \mathrm{~cm}$ dari tanaman legum, selanjutnya analisa kandungan Nitrogen $(\mathrm{N})$ pada tanah dengan metoda Kjeldahl (AOAC 2005).

\section{Analisis Data}

Rancanga yang digunakan yaitu rancangan acak lengkap (RAL) yang terdiri dari 4 perlakuan spesies legum (Stylosanthes guianensis, Arachis glabrata, Clitoria ternatea, dan Chamaecrista rotundifolia), setiap pelakuan terdiri atas 3 ulangan. Analisis data dengan Anova, bila terdapat perbedaan yang nyata $(\mathrm{P}<0,05)$ dilanjutkan dengan uji jarak berganda Duncan.

\section{HASIL DAN PEMBAHASAN}

\section{Karakteristik morfologi}

Karakteristik morfologi beberapa tanaman legum disajikan pada Tabel 1. Dari data yang diperoleh tanaman Stylosanthes guianensis merupakan tanaman yang tertinggi $(78,03 \mathrm{~cm})$, tidak berbeda nyata dengan Clitoria ternatea $(61,37 \mathrm{~cm})$, namun berbeda nyata pada tanaman Arachis glabrata dan Chamaecrista 
Tabel 1. Karakteristik Morfologi Beberapa Spesies Tanaman Legum Dalam Sistem Integrasi Dengan Tanaman Jeruk

\begin{tabular}{|c|c|c|c|c|}
\hline Parameter & Arachis glabrata & Stylosanthes guianensis & Clitoria ternatea & Chamaecrista rotundifolia \\
\hline Tinggi tanaman $(\mathrm{cm})$ & $33.03 \pm 7.53^{\mathrm{b}}$ & $78.03 \pm 15.90^{\mathrm{a}}$ & $61.37 \pm 6.13^{\mathrm{a}}$ & $25.00 \pm 1.00^{\mathrm{b}}$ \\
\hline Lebar daun (mm) & $15.11 \pm 4.58^{\mathrm{C}}$ & $10.82 \pm 3.13^{C}$ & $31.14 \pm 3.14^{a}$ & $18.56 \pm 2.85^{b}$ \\
\hline Panjang daun (mm) & $38.93 \pm 10.17^{a b}$ & $31.09 \pm 5.37^{\mathrm{bc}}$ & $47.27 \pm 6.31^{a}$ & $25.09 \pm 0.48^{c}$ \\
\hline Jumlah daun (helai) & $125.46 \pm 8.69^{a}$ & $93.08 \pm 6.46^{a b}$ & $50.48 \pm 10.22^{C}$ & $77.46 \pm 37.44^{b c}$ \\
\hline Fraksi daun (\%) & $55,23 \pm 5,69^{a b}$ & $44,82 \pm 2,64^{b}$ & $55,08 \pm 5,56^{a b}$ & $63,95 \pm 9,99^{a}$ \\
\hline Fraksi batang (\%) & $44,77 \pm 5,69^{a b}$ & $55,18 \pm 2,64^{a}$ & $44,92 \pm 5,56^{a b}$ & $36,05 \pm 9,99^{b}$ \\
\hline Rasio daun:batang & $1,26 \pm 1,00^{a b}$ & $0,81 \pm 0,09^{b}$ & $1,23 \pm 0,25^{a b}$ & $1,77 \pm 0,93^{a}$ \\
\hline Warna batang & Hijau & Hjau muda & Hijau muda & Hijau muda \\
\hline Warna daun & Hijau muda & Hijau & Hijau muda & Hijau muda \\
\hline Warna kelopak bunga & Tidak berbunga & Kuning & Biru tua & Kuning \\
\hline Warna biji & Tidak berbiji & Kuning kecoklatan & Hitam & Coklat muda \\
\hline
\end{tabular}

Keterangan: Angka yang diikuti superskrip yang berbeda pada kolom yang sama menunjukkan perbedaan yang nyata $(P<0,05)$

rotundifoila, masing-masing memperoleh tinggi 33,03 dan 25,ocm. Daun yang paling lebar dimiliki oleh Clitoria ternatea $(31,14 \mathrm{~mm})$, berbeda nyata $(\mathrm{P}<0.05)$ terhadap Chamaecrista rotundifolia $(18,56 \mathrm{~mm})$, dan Arachis glabrata $(15,11 \mathrm{~mm})$, yang terendah dimiliki oleh Stylosanthes guianensis (10,82mm). Daun yang terpanjang terdapat pada jenis Clitoria ternatea $(47,27 \mathrm{~mm})$ sedangkan terpendek $(\mathrm{P}>0,05)$ diperoleh Chamaecrista rotundifolia (25,09mm). Jumlah daun terbanyak yang dihasilkan pada saat pemotongan (panen) dimiliki oleh Arachis glabrata (125,26 helai), berbeda nyata $(\mathrm{P}<0,05)$ terhadap Chamaecrista rotundifolia dan Clitoria ternatea, masing-masing 77,46 dan 50,48 helai). Dalam hal ini, meskipun Clitoria ternatea memiliki lebar dan panjang daun tertinggi, namun jumlah daunnya yang dimiliki paling sedikit diantara ketiga jenis legum lainnya. Menurut Smart (1998); Shehu et al. (2001); Gustavsson dan Martinsson (2004) sangat penting untuk mengetahui proporsi daun karena bagian tersebut sangat disukai oleh ternak dan mengandung nutrisi yang tinggi dibandingkan dengan batang/ranting.

Fraksi daun tertinggi diperoleh Chamaecrista rotundifolia (63,95\%), dengan rasio daun:batang 1,77, tidak berbeda nyata terhadap Arachis glabrata dan Clitoria ternatea, masing-masing (55,23 dan 55,08\%) dengan rasio daun:batang 1,26 dan 1,23, namun berbeda nyata terhadap Stylosanthes guianensis meskipun memiliki tinggi tanaman yang lebih tinggi dari ketiga spesies legum tersebut, fraksi daunnya lebih rendah $(44,82 \%)$ dengan rasio 0,81 . Menurut Djuned et al. (2005), tingginya rasio daun:batang pada tanaman hijauan pakan sangat berpengaruh terhadap konsumsi dan kandungan nutrisi. Efektif terhadap kecernaan yang diperoleh (Belanger dan Banesmo. 2002).

Warna daun dan batang yang terbanyak diperoleh pada tanaman legum dalam penelitian ini adalah hijau muda (Arachis glabrata, Clitoria ternatea dan Chamaecrista rotundifolia), sementara jenis Stylosanthes guianensis memiliki daun berwarna hijau, hal ini kemungkinan besar karena lebih tingginya tanaman tersebut dibandingkan dengan ketiga spesies lainnya, sehingga lebih banyak memperoleh sinar matahari, sedangkan tanaman yang lebih rendah akibat ternaungi oleh tanaman jeruk kemampuan untuk memperoleh sinar matahari lebih sedikit sehingga klorofil (zat hijau daun) yang diproduksi lebih sedikit (Janet dan Prabhat ,2009). Warna kelopak bunga pada tanaman Stylosanthes guianensis dan Chamaerista rotundifolia berwarna kuning, sedangkan Clitoria ternatea berwarna biru

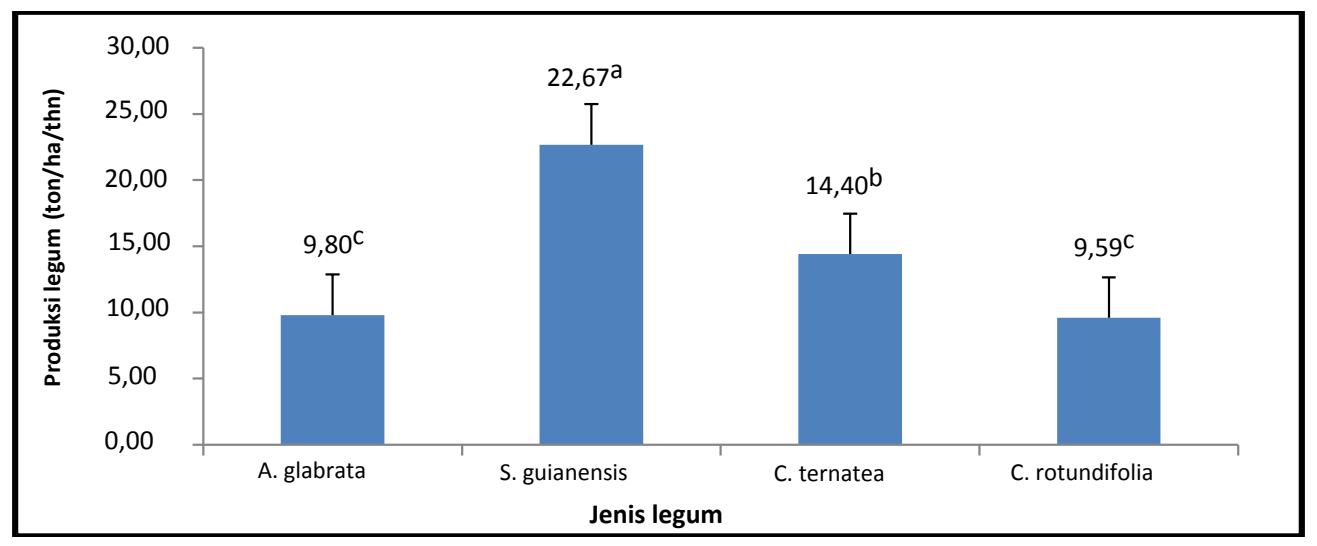

Gambar 1. Rataan produksi BK (ton ha-1 tahun-1) pada beberapa spesies tanaman legum dalam sistem integrasi dengan tanaman jeruk. 
Tabel 2. Rataan Komposisi Kimiawi Beberapa Spesies Tanaman Legum Dalam Sistem Integrasi Dengan Tanaman Jeruk

\begin{tabular}{|c|c|c|c|c|c|}
\hline Jenis tanaman & BK & BO & Abu & PK & SK \\
\hline & & & .....\%..... & 갈. & \\
\hline Arachis glabrata & $23,23^{b}$ & $87,65^{a}$ & $12,35^{\mathrm{a}}$ & $16,83^{a b}$ & $37,09^{a}$ \\
\hline Stylosanthes guianensis & $27,72^{a}$ & $88,54^{a}$ & $11,46^{\mathrm{a}}$ & $15,01^{b}$ & $32,75^{b}$ \\
\hline Clitoria ternatea & $23,01^{b}$ & $86,66^{a}$ & $13,34^{a}$ & $18,16^{\mathrm{a}}$ & $29,80^{b}$ \\
\hline Chamaecrista rotundifolia & $17,20^{\mathrm{C}}$ & $87,43^{a}$ & $12,57^{\mathrm{a}}$ & $13,13^{\mathrm{C}}$ & $32,55^{\mathrm{b}}$ \\
\hline
\end{tabular}

Keterangan: Superskrip yang berbeda pada kolom yang sama menunjukkan perbedaan yang nyata $(P<0,05)$

tua, sementara jenis Arachis glabrata tidak memiliki bunga dan tidak berbiji.

\section{Produksi bahan kering (BK)}

Hasil analisis variansi menunjukkan bahwa produksi BK tanaman legum Stylosanthes guianensis dalam sistem integrasi dengan tanaman jeruk merupakan produksi tertinggi 22,67 ton $\mathrm{ha}^{-1}$ tahun $^{-1}$ ), berbeda nyata $(\mathrm{P}<0,05)$ terhadap produksi ketiga jenis tanaman legum lainya. Masing-masing memperoleh: 14,40 ton ha ${ }^{-1}$ tahun $^{-1}$ (Clitoria ternatea), 9,80 ton ha ${ }^{-1}$ tahun $^{-1}$ (Arachis glabrata) dan 9,59 ton ha ${ }^{-1}$ tahun $^{-1}$ (Chamaecrista rotundifolia).

Tingginya produksi Stylosanthes guianensis mengidikasikan tanaman tersebut lebih toleran terhadap naungan tanaman jeruk, 70\% intensitas matahari yang masuk ke bawah naungan tanaman njeruk seluruhnya dapat ditampung dan dimanfaatkan oleh Stylosanthes guianensis. Hal ini kemungkinan besar karena lebih tingginya tanaman Stylosanthes guianensis mencapai $78,03 \mathrm{~cm}$ (Tabel 1) dibanding ketiga jenis legum lainnya. Cahaya matahari yang diperoleh Stylosanthes guianensis cukup untuk proses fotosintesis menghasilkan ketersediaan energi untuk pertumbuhan dan perkembangan tumbuhan sehingga berpengaruh terhadap roduksi biomassa tanaman (Hatfield et al., 2011).

\section{Komposisi kimiawi}

Komposisi kimiawi keempat spesies legum ditampilkan pada Tabel 2. Kandungan bahan kering (BK) tertinggi $(\mathrm{P}<0,05)$ dimiliki oleh Stylosanthes guianensis (27,72\%), Arachis glabrata dan Clitoria ternatea memililki BK yang relatif sama, masingmasing 23,23 dan 23,01\%, sementara BK pada Chamaecrista rotundifolia adalah yang terendah (17,20\%). Kandungan bahan organik dan abu yang dihasilkan tergolong moderat dan relatif sama berkisar antara 86,66-88,54\% dan 11,46-13,34\%.

Kandungan Protein kasar (PK) tertinggi pada Clitoria ternatea $(17,16 \%)$, tidak berbeda nyata terhadap Arachis glabrta (16,83\%), namun ( $\mathrm{P}<0,05)$ terhadap Stylosanthes guianensis $(15,01 \%)$ dan Chamaecrista rotundifolia (13,13\%). Kandungan serat kasar (SK) terendah diperoleh tanaman Clitoria ternatea $(29,80 \%)$, tidak berbeda nyata terhadap
Chamaecrista rotundifolia (32,55\%) dan Stylosanthes guianensis $(32,75 \%)$. Namun berbeda nyata $(\mathrm{P}<0,05)$ terhadap Arachis glabrata (37,09\%).

\section{Kandungan Nitrogen Tanah}

Rata-rata konsentrasi nitrogen (N) pada tanah (Tabel 3) menunjukkan bahwa konsentrasi tersebut masih tergolong rendah dan berada dibawah ambang batas minimal. Hardjowigeno (2003) melaporkan kriteria normal adalah 2,0-3,0\%. Konsentrasi $\mathrm{N}$ tanah pada penelitian ini diawal kegiatan berkisar antara 0,15-0,17 \%. Setelah dilakukan integrasi tanaman legum dengan tanaman jeruk konsentrasi tersebut cenderung meningkat berkisar antara (0,18-0,21\%). Menurut Mishra et al. (2009) hal ini disebabkan karena ketersediaan bakteri Rhizobium yang cukup hidup pada bintil akar tanaman leguminosa mampu untuk berasosiasi secara simbiotik mutualis dengan tanaman leguminosa. Kemampuan Rhizobium meningkatkan kemampuan tanaman mengikat $\mathrm{N}$ udara, memberikan cukup N pada tanah. Dari data yang diperoleh konsentrasi tertinggi terdapat pada tanaman legum Stylosanthes guianensis (0,21\%), sedangkan terendah dimiliki oleh Clitoria ternatea $(0,18 \%)$.

Tabel 3. Rataan Konsentrasi Nitrogen (N) pada Tanah Dalam Sistem Integrasi Beberapa Spesies Tanaman Legum Dengan Tanaman Jeruk

\begin{tabular}{lcc}
\hline \multirow{2}{*}{ Jenis tanaman } & \multicolumn{2}{c}{ Rata-rata konsentrasi Nitrogen (N\%) } \\
\cline { 2 - 3 } & Awal kegiatan & Akhir kegiatan \\
\hline Arachis glabrata & $0,16^{\mathrm{a}}$ & $0,19^{\mathrm{a}}$ \\
Stylosanthes guianensis & $0,17^{\mathrm{a}}$ & $0,21^{\mathrm{a}}$ \\
Clitoria ternatea & $0,15^{\mathrm{a}}$ & $0,18^{\mathrm{a}}$ \\
Chamaecrista rotundifolia & $0,15^{\mathrm{a}}$ & $0,19^{\mathrm{a}}$ \\
\hline
\end{tabular}

Keterangan: Angka yang diikuti superskrip yang berbeda pada kolom yang sama menunjukkan perbedaan yang nyata $(P<0,05)$

\section{SIMPULAN}

Dari hasil pengamatan karakteristik morfologi menunjukkan bahwa Stylosanthes guianensis adalah tanaman tertinggi $(78,03 \mathrm{~cm})$, Clitoria ternatea memiliki daun terlebar $(31,14 \mathrm{~mm})$ dan terpanjang (47,27 mm), Arachis glabrata memiliki jumlah daun terbanyak (125,46 lembar), sedangkan Chamaecrista rotundifolia memiliki rasio daun: 
batang tertinggi $(1,77)$. Produksi BK tanaman legum tertinggi diperoleh Stylosanthes guianensis (22,67 ton ha $^{-1}$ tahun $^{-1}$ ). Komposisi kimiawi kadar BK tertinggi pada Stylosanthes guianensis (27,72\%). Sementara Clitoria ternatea memiliki PK tertinggi $(17,16 \%)$ dan SK terendah (29,80\%). Konsentrasi N pada tanah naik pada akhir kegiatan, tertinggi pada perlakuan Stylosanthes guianensis (0,21\%). Disimpulkan bahwa jenis Stylosanthes guianensis dan Clitoria ternatea merupakan tanaman yang banyak keunggulan sebagai sumber pakan dan cover crop dalam sistem integrasi dengan perkebunan jeruk. Selanjutnya disarankan perlu dilakukan pengamatan lebih lanjut untuk mengetahui pengaruh tanaman legum terhadap produksi buah jeruk dan pemanfaatan tanaman legum terhadap produktivitas ternak.

\section{REFERENSI}

AOAC. 2005. Method of Analisis. 18 th ed. Association of Official Analytical Chemists. PO BOX 504, Benjamin Franklin Station Washington DC.

Bélanger and Bonesmo H. 2002. Timothy yield and nutritive value by the CATIMO Model: II. Growth and nitrogen. J Agron. 94: 337-345.

Gustavsson AM and Martinsson K. 2004. Seasonal variation in biochemical composition of cell walls, digestibility, morpholo-gy, growth and phenology in timothy. Eur. J. Agron.20:293-312.

Hardjowigeno S. 2003. Ilmu Tanah. Akademika Pressindo, Jakarta.

Horne PM and Stur W. 1999. Developing Forage Technologies with Smallholder Farmers. How to select the best varieties to offer farmers in Southeast Asia. Published by ACIAR and CIAT. ACIAR Monograph No.62 P: 68.
Janet V and Prabhat KS. 2009. Photoinhibition and photosynthetic acclimation of rice (Oryza sativa L. cv Jyothi) plants grown under different light intensities and photoinhibited under field conditions. J Biochemistry \& Biophysics. 46. 253-260.

Mansyur SH. 2008. Pengaruh Inokulasi Rizhobium terhadap pembentukan bintil akar kacang tanah (Arachis hipogea) ditaman hutan raya Provinsi Bengkulu. Balitbang Mikrobiologi, Puslitbang Biologi - LIPI. 39145-o-prosiding_abdul_ cholik_423_-_430.PDF.

Mishra S, Sharma S, Vasudevan P. 2009. Effect of Single and Dual Inoculation with Rhizobium and AM Fungi on Nodulation, Fodder Production and Quality in Two Stylosanthes Species. Biol. Agric. Hortic. 26: 411-421.

Moulin L, Munive J, Dreyfus B, Bolvin MC. 2001. Nodulation of Legums by Members of the subclass of Proteobakteri. Macmillan Magazines Ltd.

Saraswati R, Hastuti RD, Sunarlin N, Hutamu. 1996. Penggunaan Rhizoplus Generasi 1 untuk meningkatkan Produksi Tanaman Kedelai. Balai Penelitian Bioteknologi Tanaman Pangan, Bogor Indonesia.

Shehu Y, Alhassan WS, Phillips CSJ. 2001. Yield and chemicalcomposition response of Lablab purpureus to nitrogen, phosphorous and potassium fertilizer. J.Trop. Grassl. 35: 180-185.

Smart AJ, Schacht WH, Pedersen JF, Undersander DJ, Moser LE. 1998. Prediction of leaf:stem ratio in grasses using near infrared reflectance spectroscopy. J. of Range Management Archive. Vol. 51, no 4.

Hatfield JL, Sauer TJ, Prueger JH. 2001. Managing soils to achieve greater water use efficiency. A review Agronomy Journal 93:271-2. 